ROCZNIKI HUMANISTYCZNE

Volume 67, issue 3 - 2019

SELECTED PAPERS IN ENGLISH

DOI: http://dx.doi.org/10.18290/rh.2019.67.3-3en

WOJCIECH KOPEK

\title{
ELEMENTS OF THE MIME IN HORACE'S EPODE “QUID TIBI VIS, MULIER”
}

History has been exceedingly kind to Horace's oeuvre. It has preserved all (or nearly all) of the poet's works, with a structure that was probably his own. What is more, we even know the publication dates of particular books, and we can reconstruct the poet's biography, his affiliation with a particular group of artists, his milieu, political connections, etc. Still, the question arises: Do we really "possess" his oeuvre? Is it legitimate to say that the contents of his works are known to us? Drawing on Jacobson's theory, contemporary literary theories more and more often point not only to the text itself, but also to the context - to the specificity of the virtual audience assumed by the author. Theorists raise the issue of how metaphor is to be understood; according to Max Black, it relies on "a system of banal associations" "banal," it should be added, for the primary audience, whose members are part of a given culture. What proportion of these contextual banalities is given to us, contemporary people? Not knowing their original number, we cannot possibly determine this. It is a truism to say that the more you discover, the more there remains to discover. For this reason, the most important thing at the current stage of research on ancient culture is to reconstruct the context and to interpret-or, if necessary, to reinterpret-literary

Wojciech KopeK, MA - doctoral student at the Institute of Classical Studies of the John Paul II Catholic Uniersity of Lublin; e-mail address: Quidtibivis@wp.pl

The Polish version of the article was published in Roczniki Humanistyczne vol. 61, issue 3 (2013).

${ }^{1}$ See: Max Black, "Metaphor," Proceedings of the Aristotelian Society, New Series, Vol. 55 (1954-1955): 273-294. 
works. This is particularly important in the case of those artists who have permanently entered the world's literary canon, so that we can be sure that we have reconstructed their statues correctly and that we are not gilding the patina which ought to be chipped away. It is precisely the reconstruction of the literary and social context of one of the Horatian epodes that the deliberations below are devoted to.

Scholars exploring Horace's oeuvre have found elements of drama in his works for a long time. Kenneth Quinn pointed to Theocritus as a source of inspiration, particularly to his bucolic agon in pastoral poems ${ }^{2}$; Krystyna Zarzycka-Stańczak drew attention to the lyrical subject's situation of "intimate conversation" with the addressee in the Venusian poet's works ${ }^{3}$; similarly, Lancelot Patrick Wilkinson underscored the poet's interest in Plautus, Menander, and Terence. ${ }^{4}$ The aim of the present article is to demonstrate that the above set of inspirations found in Horace should be supplemented with the literary mime of the Hellenistic period, particularly with the works of Herondas. For this purpose, the analysis will cover the main motifs, literary character types, as well as the formal and rhetorical structure of Epode 12,

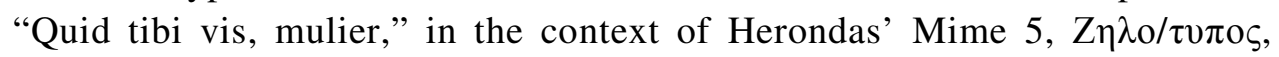
("The Jealous Woman"). ${ }^{6}$

Mime 5, "The Jealous Woman,"7 presents an argument between Bitinna, the owner of the house in which the action takes place, and her slave Drechon, nicknamed Gastron. The cause of the argument is Drechon's

\footnotetext{
2 "Horace takes over the traditional form of amoebean pastoral, in which two singers exchange snatches of verse, each trying to outdo the other within the same number of lines and following the wording and structure of his rival as closely as possible" (as cited in: Kenneth QuinN, Horace. The Odes (Hong Kong: Nelson, 1992), 261 [with reference to Carm. 3.9, "Donec gratus"]. Apart from pastoral poems, Theocritus authored works known as urban mimes.

${ }^{3}$ Krystyna ZarzyCKa-STAŃCZaK, "Pieśni miłosne Horacego", Roczniki Humanistyczne 17, no. 3 (1969): 71-72.

${ }^{4}$ Lancelot Patrick Wilkinson, Horace and His Lyric Poetry (Cambridge: Cambridge University Press, 1968): 133.

${ }^{5}$ See: Quintus Horatius Flaccus, Dzieła wszystkie, vol. 1: Ody i epody, ed. Oktawiusz Jurewicz, 418-420 (Wrocław: Ossolineum, 1986).

${ }^{6}$ All quotations are taken from the original text, as cited in: Herodas, Mimiambi, ed. Ian Campbell Cunningham (Leipzig: BSB B.G. Teubner Verlagsgesellschaft 1987).

${ }^{7}$ The Polish translations cited in the Polish version of this article are Janina Ławińska-Tyszkowska's (Herondas, Mimy, trans. Janina Ławińska-Tyszkowska, Wrocław: Wydawnictwo Dolnośląskie, 1988); the English translations of the fragments of Mime 5 cited in the English version of the paper are R. Thomson Clark's (The Characters of Theophrastus. The Mimes of Herodas. The Tablet of Kebes, trans. and introd. by R. Thomson Clark, New York, NY: Routledge, 2018).
} 
betrayals; his duty is to satisfy the sexual needs of his mistress (this is the purpose for which he was bought ${ }^{8}$ ), but he does not do this duty properly; in addition, he secretly meets Amphytaia, probably a free woman, the wife of a man called Menon (which increases the scandal). The slave rejects the charges, though he obviously has something on his conscience, as his "testimony" is

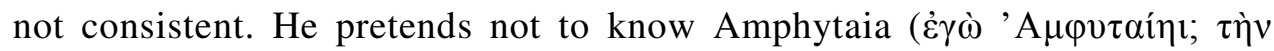
$\lambda \varepsilon ́ \gamma \varepsilon ı \varsigma$ ỏ

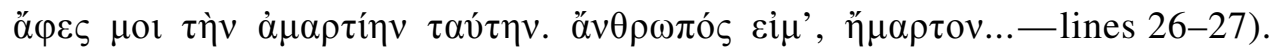
The angry woman orders for him to be tied up, stripped, and led down the main street to the "institution" where punishment is meted out to slaves for a fee. Gastron is to receive two thousand lashes, which will probably mean his death. The slave is led out by another slave, but a moment after they have left Bitinna changes her mind. She decides to have Drechon stigmatized, so that he bears the sign of slavery tattooed on his forehead until the end of his life. This punishment is not administered either, because Drechon is spared at the request of a young female slave, Kydilla, Bitinna's substitute for her daughter who died in childhood. The mime ends with Bitinna's announcement that immediately after the approaching feast of the dead, as soon as offerings have been made, the punishment will be meted out after all ( $\dot{\varepsilon} \pi \varepsilon \dot{\alpha} v$

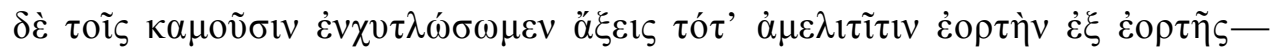
lines 84-85). The course of the entire argument, the way Gastron excuses himself, as well as Bitinna's and other characters' behavior suggest that we are witnessing a "domestic" row that probably occurs periodically.

Epode 12 has a clear dual structure: lines 1-13 are the protagonist's words in direct speech, whereas lines 14-26 are quoted words of the female lover, referred to at the beginning as mulier, also in direct speech. The text

\footnotetext{
${ }^{8}$ The price named by Bitinna - three minas - may suggest that Drechon used to be a free man and was sold into slavery as an adult. Perhaps this is the source of his waywardness in the

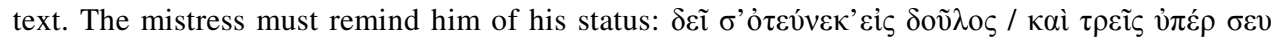

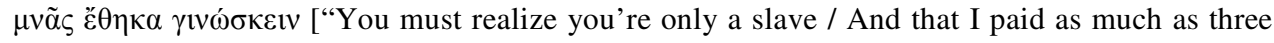
minas for you"] (lines 20-21). William Tarn reports that free people who were captured and bought (3.3 minas) were two minas cheaper than those born as slaves (5.3 minas) (William TARN, Cywilizacja hellenistyczna, trans. Cezary Kunderewicz Warszawa: PWN 1957, 172-173). The data cited here are for the $3^{\text {rd }}$ century BC, the period that Herondas' works are dated to. See: ŁAWIŃSKA-TYSZKOWSKA, "Wstęp" [Introduction], in HerondAs, Mimy, 5. The fact that Bitinna could only afford one of the cheaper slaves, even though she claims she paid a high price, attests to her middle-class background. Moreover, it can be concluded that she represents a specific mentality-characteristic not so much of her community in general, as of certain types of people that the author himself may have observed.
} 
begins with the lover's aggressive question about the reasons for the mulier's interest in him: "Quid tibi vis, mulier nigris dignissima barris?", What follows is a self-presentation of the protagonist-a young man, not fully mature yet but endowed with sharp wit and intelligence, which is conveyed by the metaphor of the nose. Pursuing the olfactory associations, the young man faults the woman for smelling badly as well as having a polyp in her nose ${ }^{10}$ and excessive body hair: "namque sagacius unus odoror, / polypus an gravis hirsutis cubet hircus in alis / quam canis acer ubi lateat sus." Next, there appears a contrast, very typical in descriptions of older women, between the "ugliness of old age" and excessive sexual appetite:

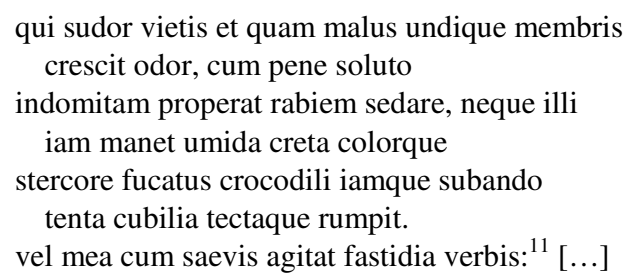

\footnotetext{
${ }^{9}$ This question, unambiguously offensive, immediately sets the audience in the convention of iambic poetry: The mysterious "black elephants" are explained by ancient commentators in two ways. Acron stated: "Elephantis a barritu dictis; <nigris> autem certe Indis siue Mauris, qui nigri sunt (et peniti)"; Porphyrion, by contrast, wrote: "In mulierem foedam atque anum haec scribit. <Barri> autem elephanti dicuntur, unde et vox eorum <barritus> appellatur. Porro autem elephanti dicuntur auersi coire; ex quo uidetur poeta dicere, cum eis eam concumbere debere, quia illam non uideant propter deformitatem ipsius"; Acronis et Porphyrionis Commentarii in Q. Horatium Flaccum, ed. Ferdinandus Havthal (Berolini, 1864), 495-498. What echoes in the first of the above explanations, perhaps because of the reference to Indis (Indic people), is the Indian tradition of love treatises. In Kamasutra, whose author mentions many of his predecessors, the following types of women are distinguished: gazelle, mare, and cow elephant-listed in order of the size of genitals (and, consequently, in order of erotic needs and appropriate lovers), from the smallest to the largest (see: VatsyayanA, The Kama Sutra of Vatsyayana [ebook], trans. Richard Burton, Bhagavanlal Indrajit, Shivaram Parashuram Bhide, Gutenberg Project, 2009: 38-39. Available at: https://www.gutenberg.org/files/27827/27827-h/27827-h.htm [Accessed 3 Oct. 2019].).

${ }^{10}$ The word polypus is a difficult one to interpret. It presumably performs several function. First, the fact that the young man's nose (the locus of shrewdness and intelligence) is not overfat or swollen while the mulier has a polyp in her nose may suggest that she is not particularly intelligent. Second, according to Plezia (Stownik tacińsko-polski, ed. Marian Plezia, Warsaw: PWN, 2007), the word polypus metaphorically referred to someone who usurped or appropriated everything, which means it may refer to the female protagonist's excessive possessiveness and importunity. Third, if we follow the path of olfactory associations, the word can be regarded as another taunt about the woman's odor, which she does not feel herself.

11 " [...] The sweat and nasty smell get worse all over / her wrinkled body, as my penis droops / and raging passion cools / and all the while the powdered chalk / and crocodile-shit dye run on her face as she ruts away, / breaking the bed and the canopy over it, / and giving me an earful for
} 
It should be noted that Horace made exaggerated use of the motif of anus ebria, whose characteristics (apart from the principal drunkenness) include excessive sexuality, inappropriate to the dignity of advanced age. ${ }^{12}$ The protagonist of the epode is a mulier, definitely not an old lady (anus), but not a puella or a virgo any more. Although it is impossible to specify her age, it is legitimate to say that, in the male protagonist's eyes, she becomes not so much "old" as "too old." Thus, the presence of this motif is another form of iambic spite - much more subtle, admittedly, but all the more hurtful.

The last line of the fragment cited above introduces the women's words in the form of a quotation. The mulier's charges against the male protagonist seem to be typical too. The first one concerns "betrayal"-or, more accurately, the lack of commitment:

Inachia langues minus ac me;

Inachiam ter nocte potes, mihi semper ad unum mollis opus. $[\ldots]^{13}$

Let us note that it sounds very similar to Bitinna's reproach to Drechon in Herondas' Mime 5. ${ }^{14}$ Mulier's reproachful remarks turn into curses against Lesbia, who introduced the protagonists to each other, and then into recollections of her previous lover, Amyntas of Cos, and his extraordinary potency. After contrasting the woman's efforts ("muricibus Tyriis iterate vellera lane / cui properabantur?"-lines 21-22) with the young man's ingratitude, the epode ends in an exclamation of despair.

being so choosy" (lines 7-13; the Polish translations of Epode 12 in the Polish version of this article are Andrzej Lam's; the English translations provided in the English version of the paper are David West's and have been cited from: Horace, The Complete Odes and Epodes, trans. David West (Oxford: Oxford University Press, 1997).

${ }^{12}$ See: Jadwiga Czerwinska, "Graus methyse - anus ebria," in Fonctions de l'anecdote dans "Les Euvres Pharmaceutiques" de Jean de Renou (1626), in Le cabinet du curieux. Culture, savoirs, religion de l'Antiquité à l'Ancien Régime. Études et essais en l'honneur de Jean-Paul Pittion, éd. M. Kozluk and W. K. Pietrzak (Paris: Éditions Classiques Garnier, 2012), 33-47.

13 "[...] You're not so slack when lying with Inachia. / Inachia you manage three times a night, but you flop / at the thought of doing me once" (lines 14-16, trans. D. West).

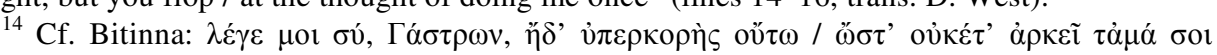

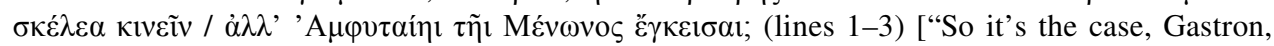
that you're so amorous that you're not content merely with my love but you carry on with Me-

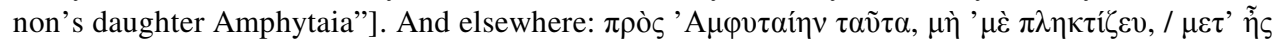

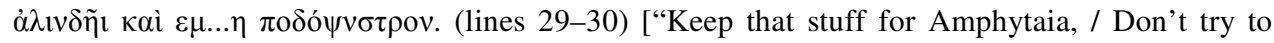
soft-soap me, me whom you dallied with and now flout, you wretched door-mat"]. 
o ego non felix, quam tu fugis, ut pavet acris agna lupos capreaeque leones!

Being a quotation, however, this sounds ironic and parodic when uttered by the male lover.

Even if the dynamism of this work suggests the form of a dialogue between the lovers, it should be remembered that this is an apparent dialogue, a kind of sermocinatio, ${ }^{15}$ whose content is obiurgatio. Obiurgatio can be regarded as a genus dicendi, although it is rather a manner of speaking. According to the principles of rhetoric, to have the right to issue a reprimand, an orator had to speak from a high moral position, such as that of a statesman or a sage. Quintillian distinguishes two levels of aptum: "quid expediat [utilitas]" and "quid deceat [honestum]": "Illud est diligentius docendum, eum demum dicere apte qui non solum quid expediat sed etiam quid deceat inspexerit. Nec me fugit plerumque haec esse coniuncta: nam quod decet fere prodest, neque alio magis animi iudicum conciliari aut, si res in contrarium tulit, alienari solent" (Quint. 11.1.8). Together they make up the ideal of dicere apte. This should not be considered a merely utilitarian or aesthetic requirement; it is, above all, a moral imperative that applies to the audience as well! A similar point was made by Plato (Gorgias 508c), who claimed that the orator must be a righteous man and must, additionally, be a good judge of what is just. In this way, according to Lausberg, ${ }^{16}$ the orator's virtutes were linked with the virtutes of the work. Nevertheless, Quintillian is aware that the two levels of aptum do not always go together (Quint. 11.1.9), in which case it is honestum that should prevail. But when this happens, the orator may invoke the principle of monere. ${ }^{17}$ What serves to tone down the bitter effect of a just reprimand is the figure of licentia or

${ }^{15}$ All Latin rhetorical terms, which are italicized in the text, have been taken from: Heinrich LAUSBerg, Retoryka literacka. Podstawy wiedzy o literaturze, trans. and ed. Albert Gorzkowski (Bydgoszcz: Homini, 2002). According to Lausberg, sermocinatio is "the fabrication of statements, conversations, soliloquies, or unuttered thoughts of the persons (historical or fictional) who are the subject of the utterance; it serves the purpose of better characterization" [ibid., 450; “jest zmyśleniem stwierdzeń, rozmów, solilokwiów lub niewyrażonych głośno refleksji osób (historycznych albo fikcyjnych), będących przedmiotem wypowiedzi, służy zaś ich lepszej charakteryzacji”].

${ }^{16}$ Ibid., 39.

${ }^{17}$ Ibid., 147. Lausberg puts monere, prodesse, and docere on a par, in the sense that they may all be accompanied by taedium. Accordingly, the rhetor or poet (Hor. Ars 333-365) must give their good advice or admonitions in a more "palatable" form that will be appropriate for a particular audience. 
sermocinatio ${ }^{18}$ which effectively defends the speaker against the audience's aversion, because the reproach comes "from someone else's mouth, with the orator acting only as a "medium." Quintillian (9.2.29) stated: "suadendo obiurgando querendo laudando miserando personas idoneas damus." It seems rhetorical theory can be used to create literary characters appropriate for the dramatic situations or the "plot" designed by the author. Protagonists present themselves; in the course of the work they also make decisions consistent with their character, thus pushing the plot in the right direction.

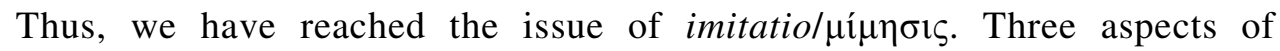
"imitation" present in Epode 12 should be distinguished: imitation of reality, genre, and person. Sermocinatio ${ }^{19}$ is associated with figures-prosopopoeia, ethopoeia (reflection of character), and pathopoeia (reflection of violent momentary emotions) - thanks to which, someone else's character is imitated; as stated by the author of the Rhetorica ad Herennium (Rhetoric: For Herennius, 9.2.58): “imitatio morum alienorum, quae $\grave{\eta} \theta$ o $\pi$ otía vel, ut alii malunt, $\mu$ í $\eta \imath_{\iota} \varsigma$ dicitur; iam inter leniores affectus numerari potest; est enim posita fere in eludendo sed versatur et in factis et in dictis." These figures have been defined by numerous rhetors and speech theorists, but what draws attention in the definition cited above is the component of mockery and play (a kind of "game"): eludere. This indirectly leads to a figure that appears not to have a Latin name or, at any rate, has not been fully defined-namely, to $\pi \alpha \rho \omega \delta \eta$. Again, this figure has two aspects: one of them literary and the other one more rhetorical. Quintilian defines "parody" as the imitation of the works, style, meter, etc. of artists by other artists (Quint. 9.2.34-35), but Lausberg $^{20}$ indicates a different possibility, defining "parody" as the "humorous presentation of a serious model," which is closer to the contemporary

\footnotetext{
${ }^{18}$ LAUSBERG, Retoryka literacka, 419-420, 450-454. Whereas licentia is admonition "proper," sermocinatio can be used as an invocation of an authority. Although the primary function of this technique consists in presenting a given character, it can be used as a form of admonition or reproach (obiurgare). In that case, the author "creates" or evokes a character who could, in a given situation, utter particular words. On the one hand, these words identify the character as having high moral standards, but at the same time it is precisely as such that this character can admonish the audience without exposing the author to taedium. It is obvious that, in this way, the author makes the character his or her mouthpiece. We can therefore speak of obiurgare in licentia, as well as about obiurgare as the content of sermocinatio. Cf. Cic. De orat. 3.211.

${ }^{19}$ It should be added that sermocinatio has also been referred to as a (fictitious) dialogue. Cf. Quint. 9.2.31; LAUSBERG, Retoryka literacka, 451. This fact seems to be particularly significant in the context of the comparison of Epode 12 to the mime, which often had the form of a fictitious dialogue between characters played by the same actor.

${ }^{20}$ LAUSBERG, Retoryka literacka, par. 824.6, 902.3b, 1143-1144.
} 
colloquial understanding of this word. ${ }^{21}$ At the same time, the scholar points out that $\pi \alpha \rho \omega \delta$ r can be treated as a "biased" imitatio, whose aim is to mock and compromise rather than to describe the adversary. In this sense, it may be regarded as a type of the figure called ironia. Without going deeper into the issues of literary irony, it should be noted that its essence is contrarium, a kind of perversity based on concealing the author's actual intentions. ${ }^{22}$

Thus, we return to Epode 12, in which the power of parody stems from the substitution of the character-types of an attacked male lover and an angry woman for the conventional figure of a sage. At the point when the sage appeals to the love of the motherland when delivering a reprimand, the character's motive is anger and jealousy-ira et invidia. This is a special kind of infringement of the external aptum, which indicates black humor in the text (iocus, risus). The epode is a monologue, but it has virtual stage dialogue potential. It is doubled obiurgatio. The man's attack followed by the woman's answer-parody make up a kind of dialogue—or, more accurately, a parody of a specific literary type of female lover, ${ }^{23}$ which has been sketched out above. This is the first of the elements worth noting. The

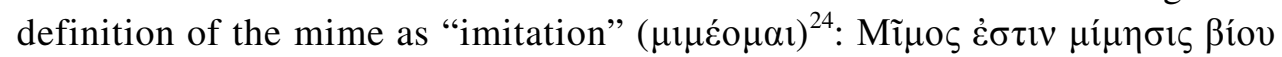

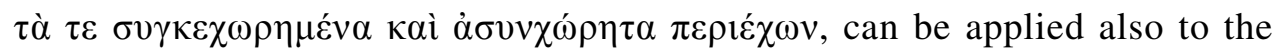
epode discussed here, on as many as two levels. Firstly, Horace presents a fictional situation of an argument between lovers. Introducing a kind of "realism" or even iambic "naturalism" 25 into the description and behavior of his characters, he at the same time intensifies the dramatic situation to the

\footnotetext{
${ }^{21}$ It is in this sense that the word "parody" will be used further in the present article.

${ }^{22}$ Lausberg discusses this issue in paragraph 610 of the cited study. Irony is discussed as a trope in paragraphs 582-585 and as a figure in paragraphs 902-904. Through contrarium, it links irony with allegory. Lausberg discusses this issue at greater length in paragraphs 423 and 896ff.

${ }^{23}$ On the parodic nature of the mime, see: Encyclopedia of the Ancient World (Brill's New Pauly), vol. 6, ed.. Hubert Cancik and Helmuth Schneider (Leiden-Boston: Brill, 2004), col. 922-923.

${ }^{24}$ Diomedes defined the mime as follows: "Mimus est sermonis cuius libet <imitatio et> motus sine reverentia, uel factorum et <dictorum> turpium cum lasciuia imitatio; a Graecis ita definitus:

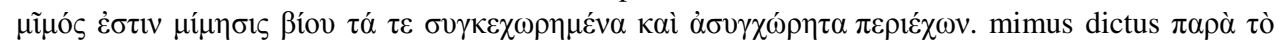
$\mu \iota \mu \varepsilon \tilde{\sigma} \sigma \alpha \iota$, quasi solus imitetur, cum et alia poemata idem faciant" ["The mime is an imitation (mimesis) of life comprising both what is allowed and what is forbidden"] (CGL, 491, 13-17).

${ }^{25}$ I put "realism" and "naturalism" in quotation marks for the following reasons: (1) they are associated with the period of positivism and therefore anachronistic with regard to ancient literature; (2) it is impossible to determine the exact definitions according to which they were applied to mimes; (3) at the same time, it is impossible to abandon them due to the principle of "mimesis"

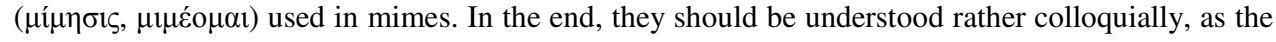
most obvious link between the world presented and reality, and this is what they will mean in the present article.
} 
point of exaggeration, as he focuses on both protagonists' characteristic traits, which results in their enhancement to nearly absurd proportions. Herondas used a similar technique in Mime V. According to Korus, ${ }^{26}$ the mimographer superimposed the "female lover-male lover" relationship onto the "mistress-slave" relationship, additionally putting the characters in a situation of infidelity and jealousy. Thus, the dramatic scene involving a case of "dual loyalty" turns from realistic to more and more absurd, ironic, and sarcastic, without losing its verisimilitude in the process. ${ }^{27}$

The second aspect of the cited definition is the actor's performance itself. It does not matter whether a given work is meant to be staged or only to be read, because being a stage genre is a distinctive feature of the mime anyway. Even typically literary mimes draw on a particular tradition. After all, mimos originally meant an actor who imitated (mimicked) human types by means of words and gestures; it only later came to refer to the mocking and bawdy performance itself. ${ }^{28}$ It is precisely this mocking imitation that is called a parody.

Accordingly, the man's obiurgatio starts with an agressive interrogatio, which does not have an interrogative function but serves the purpose of attacking the opponent: "Quid tibi vis, mulier nigris dignissima barris?" It should be added that the most important function of this figure is "to understate the opponent's value." 29 Likewise, Herondas' Mime 5 "The Jealous Woman" also begins with an interrogatio: "Bitinna: So [is it] the case, Gastron, that you're so amorous that you're not content merely with my love but you carry on with Menon's daughter Amphytaia[?]" This results from the reduction of the basic parts of drama. Mimographers have left only the epeisodion, which both prologue and exodos were merged with. ${ }^{30}$ Yet, they must have felt the absence of these elements, which had been used for a long time in dramatic genres; it seems it was for this reason that they used figures which were readily available and excellently presented in rhetoric manuals. ${ }^{31}$

\footnotetext{
${ }^{26}$ Kazimierz KoRus, “Rzeczywistość w „mimach” Herondasa,” Meander 9-10 (1994): 497-498.

${ }^{27}$ The moralizing or ethical dimension is not considered here. What is addressed is only the technique behind the construction of the two scenes.

${ }^{28}$ See: Encyclopedia of the Ancient World (Brill's New Pauly), vol. 6, col. 920.

${ }^{29}$ LAUSBERG, Retoryka literacka, 422.

${ }^{30}$ On the reduction of the five basic parts of drama in the mime, see: Korus, "Rzeczywistość w ,mimach” Herondasa,” 493-503.

${ }^{31}$ Cf. the first lines of Mime 3, "The Schoolmaster," or the prayerful invocation in Mime 4; the principle of introducing the audience in medias res can be seen in other mimes as well.
} 
The main part of the male lover's speech is a characteristic narratio, whose aim is to present facts in a biased way. Of course, what we are dealing with here is genus admirabile-in this case, iambic poetry. This means that account is not taken of what is called external aptum, the moral responsibility for words-in this case, verba humilia and sexual expressions. Let us note, however, that Horace employs neither obscenitas nor verba obscena, but-in accordance with the requirements of the external aptum mentioned above-replaces them with paraphrase and metaphor. Admittedly, these techniques do produce a certain obscenity, in a colloquial sense, the difference being that its "weight" has been transferred from verba to res. By means of his biased and obscene presentation of the woman (mulier), the boy, who is "no sturdy youngster" (line 3) seeks to win the favor of the audience (captatio benevolentiae) and at the same time to discredit the female lover. This is a form of invidia ab adversariorum persona, obtained by means of argumenta a persona and argumenta ad personam. Moreover, as the narratio develops, it unfolds the literary character type of the female lover which is going to be parodied. This is an additional piece of information for the reader to work out what literary convention the epode draws on. The first part brings information about the kind of relationship between the young man and the woman (iuvenis and mulier, the age difference issue) and about his ambiguous financial dependence on her (munera-line 2). Next, there is the previously mentioned presentation of the literary character type of a woman. ${ }^{32}$ First of all, she is a mulier, a woman no longer young and probably married. Her age in the protagonist's eyes implies the corresponding appearance. What attests to the fact that she represents a type is her unusual and insatiable sexual appetite. The source and "natural habitat" of this motif is the mime..$^{33}$ The female character type of interest to us is found precisely in Herondas' Mime 5, "The Jealous Woman." Its protagonist, writes Janina Ławińska-Tyszkowska, is "a wanton or rather

\footnotetext{
${ }^{32}$ It is worth noting the interesting description of the female figure: excessive make-up, vulgar behavior, and above all - the comparison to a billy goat (hircus). Some resemblance to the presentations of Faun can be found here. The symbolism of the goat (a reference to Old Comedy) and hair as a sign of excessive sexual appetite, as well as the juxtaposition of woman with nature (inguen-collis, as well as subare) opens interesting research perspectives not only for literary studies, but also for cultural anthropology.

${ }^{33}$ See ŁaWińsKa-TySZKowsKa, "Wstęp" [Introduction], in Herondas, Mimy, 9; Encyclopedia of the Ancient World (Brill's New Pauly), vol. 6, col. 251-254; ibid., vol. 8, col. 920-926.
} 
insatiate woman." ${ }^{34}$ The woman, Bitinna, has a slave named Drechon, whose task is to pleasure her. But the slave does not serve his mistress with due zeal, and Bitinna even suspects that he betrays her. This makes her so furious that she curses the day when the slave came to live in her house: "Curses on the day that brought you here!" 35 The female protagonist of Epode 12 expresses her anger and bitterness about her meeting with the indolent lover in a similar way, the difference being that she speaks to Lesbia, who once introduced the two lovers to each other: "pereat male quae te / Lesbia quaerenti taurum monstravit inertem." Apart from irritation, in both works we are dealing with a grotesque form of jealousy: jealousy not of the feelings but of the services of the slave/lover/kept man. It will be necessary to return to this motif later, but now let us follow the course of the epode. Having presented the accusation, the male protagonist "gives" the floor to the female lover. He does this only virtually, though, as we must remember that the same actor who played the male role now plays the female role. We are, however, not dealing with only two levels: actor and character. The female lover's speech reveals an additional level of the relationship: first, the actor plays the lover (iuvenis), and then the man he plays "mimics" the woman (mulier). This triple relationship suggests that Epode 12 can be called parodic. Regardless of the actor, it is still necessary to comment on the issue of "points of view." The two-part structure of the text may suggest that two points of view have been presented in it, but one could not be further from the truth. From the beginning until the end of the text, the dramatic situation consistently revolves around the male character. Paradoxically, it is not until the second part of the poem (the female lover's apparent speech) that the main ideas of the epode are sketched. Firstly, the woman (parodied by the male lover, acting as an actor-a mime, an imitator) confirms that she represents the unsatisfied female lover character type: "Inachia langues minus ac me; / Inachiam ter nocte potes, mihi semper ad unum / mollis opus" (lines 14-16); "quaerenti taurum" (line 17). The main motif in her speech is another female obiurgatio. What should be noted, however, is the manner in which it is constructed. The woman does not demand exclusiveness stemming from the solemn feeling of love between her and the man; their relationship is based on the service the man provides. What the female protago-

\footnotetext{
${ }^{34}$ ŁAWIŃSKA-TYSZKOWSKA, "Wstęp," 9.

${ }^{35}$ Ibid., 53 (lines 22-23). In the original text, "curse" has a negative dimension: $\omega \varsigma \mu$ ทे

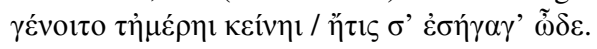


nist demands from him is at least the same commitment that he shows towards Inachia. Thus, the man has been deprived of the human/masculine dimension and reduced to his body only; his body has been further reduced to a source of pleasure. It is precisely in this objectification ${ }^{36}$ of the male body that the deepest resemblance to Herondas' Mime 5 can be seen. After all, the latter work presents a mistress-slave/lover relationship. Drechon had a chance to become a "gentleman"; Bitinna was willing to treat him almost as her equal. ${ }^{37}$ But he wasted that chance and remained an object, a speaking "tool," by becoming immersed in carnal relations. Horace may, to some extent, have been drawing on Mime 6, "Friends, or a Private Conversation," 38 whose "protagonist," equally with the actual characters, is a requisite in the form of a leather baubon (dildo). It is not a man any more, and not even a man's body, but an object. ${ }^{39}$ It is to the role of this kind of object that Bitinna seems to be reducing her previous lover, Amyntas (lines 18-20): "cum mihi Cous adesset Amyntas, / cuius in indomito constantior inguine nervos / quam nova collibus arbor inhaeret."

Based on the above discussion, it can be concluded that Horace's Epode 12 is a mime. From the very beginning of its existence, this genre was addressed to a male audience. ${ }^{40}$ The main themes in works representing this genre were drunkenness, violence, sexual relations, and betrayal, the characters were presented as stereotypical literary types, such as a fool, an adulterer, a flatterer, a female lover, or a procuress ${ }^{41}$ (incidentally, the role of

\footnotetext{
${ }^{36}$ See: Marek DrwiĘGA, Ciało człowieka. Studium z antropologii filozoficznej (Cracow: Księgarnia Akademicka 2002), 128ff. What is noted here is only the perspective of interpreting the work in terms of the anthropological or carnal aspects. A closer analysis requires a separate study.

37 "I've got myself to blame, Gastron, I know, for putting you on a level with gentlemen, but if I did make a mistake then, now you'll see whether Bitinna is the born idiot you think she is." (lines 14-17).

${ }^{38}$ As translated by J. Ławińska-Tyszkowska.

${ }^{39}$ Cultural differences should be noted, however, between Rome in the 1 st century BC and the Graeco-Egyptian culture of the 3rd century BC.

${ }^{40}$ Encyclopedia of the Ancient World (Brill's New Pauly), vol. 6, col. 251-254; ibid., vol. 8. col. 920-926.

${ }^{41}$ In the epode there is one other type characteristic of the mime, though also found in comedies. The previously mentioned Lesbia, who "introduced" the indolent lover to the female protagonist, is undoubtedly a procuress. This is also an element of the anus ebria motif mentioned above, since very often the "drunken crone" was into procuration. The identification of this type allows the reader to go beyond the text for the full picture of the situation that must have taken place between the protagonists. Namely, Lesbia, paid by one of them, probably by the female lover, initiated the acquaintance and acted as a go-between, making it easier for the married (?) lover to betray her husband, who is always absent in such dealings and whose absence adds the
} 
a procuress is exemplified by Lesbia, who is mentioned in the epode, lines 16-17). The mime, associated with street performances and drinking parties, had no religious connotations as tragedy or even Old Comedy did; unlike in New Comedy, authors did not have to adhere to middle class conventions: as a kind of party game at symposia, it was a product of a light atmosphere in which morals did not matter much. A trace of this is the feast (conviva-line 23) mentioned in the text, which hints at the male audience of the epode. This fact is noteworthy, since women neither watched not were regarded as the expected audience of mimes, and they most certainly could not be actresses. ${ }^{42}$ What argues for a link between the mime parodying a female lover and its (expected) audience is lines 22-24: "[...] tibi nempe, / ne foret aequalis inter conviva, magis quem / diligeret mulier sua quam te." This fragment suggests that the whole story of public scandal (lovers' row) also concerns the audience, the peers of the (supposed) actor who acts out a lover's dialogue with his woman (mulier) as part of a game during a feast. The "peers" are probably well familiar with such conversations, because they all-as this fragment suggests-have their own mulieres. The audience is therefore predisposed to receive, understand, and-consequentlyappreciate the kind of humor present in the scene, its parodic power, and at the same time its realism, since they could relate the situation to their own. The mime and the (presumed) audience must be linked not only by the same class background (the ambiguous financial dependence on mulier) but also by the common experience that the "plot" of the mime is about. Without this knowledge, the meaning of the scene does not fully unfold. With this common experience in mind, commentators speak of the "verisimilitude" of the mime, in the context of Herondas" "Jealous Woman" and Horace's epode "Quid tibi vis, mulier."

\footnotetext{
flavor of a sex scandal to the affair. Additionally, there are multiple levels of betrayal, as the unfaithful mulier is angry with and jealous of her faithless lover. The motif of a procuress apperars in Herondas' Mime 1, bearing this particular title. See: Encyclopedia of the Ancient World (Brill's New Pauly), vol. 6, col. 251-254; ibid., vol. 8, col. 920-926. An interesting comment on the motif of procuress is offered by Kazimierz Korus (Rzeczywistość w „mimach” Herondasa, 497-498).

${ }^{42}$ Which also points to the dual role of the man, first that of an angry male lover and then that of an angry female lover, parodied by the protagonist of the epode.

${ }^{43}$ Trivializing this, one can find a certain resemblance between the mime or the epode and contemporary cabaret genres, in which the power of expression and the appropriate meaning depend entirely on the political or social situations they relate to; taken out of context, they are incomprehensible and cease to amuse. Moreover, a cabaret program is prepared for a particular audience, whose "level" determines the level of the performance itself. In this sense, it is legitimate
} 
Naturally, the two scenes differ from each other. In terms of the traditional division into masculine and feminine mimes, Herondas' mime is feminine while Horace's epode is masculine, according to the point of view presented in the respective works. In some sense, however, Epode 12 comprises both types. Let us also note that although in Horace there is no mistress-slave relationship, the female protagonist's words do echo the reproach of the indolent lover-slave-the role assumed, reluctantly, by the protagonist of the epode "Quid tibi vis, mulier." Even Drechon, when cornered, responds with anger, even though he is a slave. ${ }^{44}$

The motif of the argument between the mistress and her sex slave, as well as the literary character types were processed by Horace to such an extent that it is legitimate to speak of a literary dialogue and an attempt to reformulate motifs- to translate them into a different cultural context. What may also argue for including Herondas in Horace's area of interest is the place of origin of Amyntas of Cos (line 18), the female protagonist's lover in the epode, and Horace's own social situation. Although we know next to nothing about where Herondas was from, his works are nearly always set on the island of Cos (Kos). Assuming that there are no accidental elements in the poem, this link should be regarded as noteworthy. Moreover, as suggested by Janina Ławińska-Tyszkowska, ${ }^{45}$ given Herondas' characteristic attitude to slavery, the poet may have been a freedman, which was not a rarity in those times. Is it possible that Horace felt a kind of affinity to the Greek poet? It is possible that they shared a common perspective on the world? Naturally, it is difficult to resolve this matter, but the marked similarity between Epode 12 and the mime, the thematic resemblance between Horace's epode and Herondas' mime argues for the inclusion of the mimographer among the Venusian poet's inspirations, not only iambic (with regard to content, not form), such as Archilochus, but also satirical ones, such as Lucilius. As a result, the analysis of epodes and the satires which immediately follow in the context of Hellenistic mimes $^{46}$ may reveal dimensions in the Roman poet's works that have not been discerned before.

to speak of a special kind of "realism," consisting of reference being made to a particular real situation, both in the case of the cabaret and of the mime.

${ }^{44}$ Herondas, Mime 5, lines 4-7: "Drechon: I? Carrying on with Amphytaia? Have I ever seen the woman you mean? Bitinna: There you are, excuses every time. Drechon: I'm only your slave and you can do with me what you please, But don't suck my blood both night and day."

${ }^{45}$ ŁAWIŃSKA-TYSZKOWSKA, "Wstęp," 10, 12.

${ }^{46}$ Particularly in the context of Menippean satire. The article by Kazimierz Korus, cited above, was meant to prove that Herondas was inspired by this genre in his work. Through mimiambs, Horace may also have taken an interest in this kind of satire, which may have influenced his subsequent attitude towards Lucilius and his understanding of the genre itself-for instance, its moralizing function. 


\section{BIBLIOGRAPHY}

\section{A. PRIMARY SOURCES}

Q. Horati Flacci Opera. Edited by E. C. Wickham and H. W. Garrod. Oxford: Classical Texts Series, 1912.

Q. Horati Flacci Opera. Edited by F. Klingner. Leipzig: Teubner Series, $1970^{5}$.

Herodas. Mimiambi. Edited by Ian Campbell Cunningham. Leipzig: BSB B.G. Teubner Verlagsgesellschaft, 1987.

\section{B. TRANSLATiOnS}

Herondas. Mimy [Mimes]. Translated with an introduction by Janina Ławińska-Tyszkowska. Wrocław: Wydawnictwo Dolnośląskie, 1988.

Horatius Flaccus Q. Dzieła wszystkie [Complete works]. Edited by Oktawiusz Jurewicz. Wrocław: Ossolineum, 1986.

Horace. The Complete Odes and Epodes. Translated by David West. Oxford: Oxford University Press, 1997.

Sielanka grecka [The Greek pastoral poem]. Translated by Anna Świderkówna. Wrocław: Zakład Narodowy im. Ossolińskich, 1953.

The Characters of Theophrastus. The Mimes of Herodas. The Tablet of Kebes. Translated with an introduction by R. Thomson Clark. New York, NY: Routledge, 2018.

\section{LITERARY STUDIES}

Acronis et Porphyrionis Commentarii in Q. Horatium Flaccum. Edited by Ferdinandus Havthal. Berolini: Sumptibus Julii Springeri, 1864.

BARCHIESI, Alessandro. "Horace and Iambos: The Poet as Literary Historian." In Iambic Ideas. Essays on a Poetic Tradition from Archaic Greece to the Late Roman Empire, edited by Alberto Cavarzere, Antonio Aloni, and Alessandro Barchiesi, 141-164. Boston: Rowman and Littlefield Publishers, Inc., 2001.

Black, Max. "Metaphor." Proceedings of the Aristotelian Society, New Series, Vol. 55 (19541955): 273-294.

Brill's Encyclopedia of the Ancient World, edited by Hubert Cancik and Helmuth Schneider. Leiden-Boston: Brill, 2007.

Commager, Steele. The Odes of Horace. New Haven and London: Yale University Press, 1963.

Czerwinska, Jadwiga. "Graus methyse-anus ebria." In Colloques, Congrés et Conférences sur la Renaissance Européenne 78, Le cabinet du curieux. Culture, savoirs, religion de l'Antiquité à l'Ancien Régime. Études et essais en l'honneur de Jean-Paul Pittion, edited by M. Kozluk and W.K. Pietrzak, 33-47. Paris: Éditions Classiques Garnier, 2013.

Diomedis Artis Grammaticae libri III. Edited by Heinrich Keil. In Grammatici Latini ex recensione Henrici Keilii, vol. 1 (abrev. CGL), Lipsiae: In Aedibus B.G. Teubneri, 1857.

DrwIĘGA, Marek. Ciato cztowieka. Studium z antropologii filozoficznej [The human body: A study in philosophical anthropology]. Cracow: Księgarnia Akademicka, 2002.

Hanusiewicz, Mirosława. Pięć stopni miłości [Five degrees of love]. Warsaw: Semper, 2004. 
HARRISON, Stephen J. "Some Generic Problems in Horace's Epodes: Or, On (Not) Being Archilochus." In Iambic Ideas. Essays on a Poetic Tradition from Archaic Greece to the Late Roman Empire, edited by Alberto Cavarzere, Antonio Aloni, and Alessandro Barchiesi, 165186. Boston: Rowman and Littlefield Publishers, Inc., 2001.

KoRus, Kazimierz. "Rzeczywistość w „mimach” Herondasa” [Reality in the mimes of Herondas]. Meander 9-10 (1994): 493-503.

Lausberg, Heinrich. Retoryka literacka. Podstawy wiedzy o literaturze [Literary rhetoric. Basic knowledge about literature]. Translated and edited by Albert Gorzkowski. Bydgoszcz: Homini, 2002.

Podręczny stownik terminów literackich [A concise dictionary of literary terms]. Edited by Janusz Sławiński. Warsaw: OPEN, $1999^{12}$

QuinN, Kenneth. Horace, The Odes. Hong Kong: Nelson, 1992.

Rostropowicz, Joanna. Odbicie rzeczywistości politycznej, społecznej i gospodarczej w poezji aleksandryjskiej [The reflection of political, social, and economic reality in Alexandrine poetry]. Warsaw-Wrocław: PWN, 1983.

Sielanka grecka [The Greek pastoral poem]. Translated by Anna Świderkówna, edited by Jerzy Łanowski. Wrocław: Zakład Narodowy im. Ossolińskich, 1953.

TARN, William. Cywilizacja hellenistyczna [Hellenistic civilization]. Translated by Cezary Kunderewicz. Warsaw: PWN, 1957.

VATSYAYANA, The Kama Sutra of Vatsyayana [ebook], trans. Richard Burton, Bhagavanlal Indrajit, Shivaram Parashuram Bhide, Gutenberg Project, 2009. Available at: https://www.gutenberg. org/files/27827/27827-h/27827-h.htm [Accessed 3 Oct. 2019].

Wilkinson, Lancelot Patrick. Horace and His Lyric Poetry. Cambridge: Cambridge University Press, 1968.

Watson, Lindsay C. "Epode 14: Horace's Carmen Inconditum?” In Iambic Ideas. Essays on a Poetic Tradition from Archaic Greece to the Late Roman Empire, edited by Alberto Cavarzere, Antonio Aloni, and Alessandro Barchiesi, 187-204. Boston: Rowman and Littlefield Publishers, Inc., 2001.

WóJciK, Andrzej. Talent i sztuka. Rzecz o poezji Horacego [Talent and art: On Horace's poetry]. Wrocław: Ossolineum, 1986.

ZARZYCKA-STAŃCZAK, Krystyna. "Erotyki i sympotyki w drugim zbiorze Pieśni Horacego" [Erotic and sympotic poems in the second collection of Horace's Carmina]. Roczniki Humanistyczne 23, no. 3 (1975): 59-72.

ZarZYCKA-STAŃCZAK, Krystyna. "Kilka uwag o Pieśniach Horacego" [A few comments on Horace's Carmina]. Roczniki Humanistyczne 16, no. 3 (1968): 93-106.

ZARZYCKA-STAŃCZAK, Krystyna. "Pieśni miłosne Horacego" [Horace's love songs]. Roczniki Humanistyczne 17, no. 3 (1969): 69-94.

ZARZYCKA-STAŃCZAK, Krystyna. "Problematyka literacka w Satyrach Horacego" [Literary issues in Horace's Satires]. Roczniki Humanistyczne 12, no. 3 (1964): 77-94.

ZARZYCKA-STAŃCZAK, Krystyna. "Rola aluzji i reminiscencji literackich w Satyrach Horacego" [The role of literary allusions and reminiscences in Horace's Satires]. Roczniki Humanistyczne 9, no. 2 (1960): 53-64. 


\section{ELEMENTS OF THE MIME \\ IN HORACE'S EPODE “QUID TIBI VIS, MULIER”}

\section{Summary}

The aim of this article is to discover the literary context for Horace's Epode 12 by juxtaposing it with Herondas' mimes, particularly Mime 5, titled The Jealous Woman. The description of the relationship between these works is based on the ancient theory of rhetoric and on elements of Horace's Ars poetica. It has been established that Epode 12 has numerous features of the literary mime: it is an apparent dialogue (sermocinatio, $\pi \alpha \rho \omega \delta \eta$ ) recited by a single performer (mime), most probably in the scenery of an ancient feast. A participant in the feast becomes an actor, who first performs the role of a male lover (iuvenis) and then the role of a superannuated female lover (mulier). These character types are typical of both Old and New Comedy styles, but the whole dramatic setting seems to bear the greatest resemblance to Mime 5, in which the same literary protagonists are found in a scene analogous to a lovers' quarrel. On the one hand, specific rhetorical figures (imitatio / $\mu$ í $\mu$ $\sigma \iota \varsigma$ ) indicate that the literary original was used in a creative manner. On the other, Mime 5 can also be used in the interpretation of Epode 12. This interpretation can be built on the processes of liberation and subjugation as part of the lovers' relationship (actual subjugation in Mime 5 and metaphorical-financial-in Epode 12, where the iuvenis is the mulier's "kept man").

Key words: Horace; Herondas; mime; epode; parody; iuvenis; mulier; (literary) context.

\section{Translated by Piotr Czyżewski}

The preparation of the English version of Roczniki Humanistyczne and its publication in electronic databases was financed under contract no. 836/P-DUN/2018 from the resources of the Minister of Science and Higher Education for the popularization of science. 